\title{
Reading diasporic engagements through the lens of citizenship: Turkey as a test case
}

\author{
Zeynep Yanasmayan \\ Zeynep Kaşlı
}

This is a pre-publication version of the article published in Political Geography, Volume 70, April 2019, Pages 24-33:

https://www.sciencedirect.com/science/article/pii/S0962629818301057

\section{ABSTRACT}

Diaspora policies have recently become prominent for an increasing number of states. While the growing body of literature on new diaspora policies and institutions has shown these as a sign of a state's willingness to include populations from abroad into the polity, an equally new adjacent literature has emphasised the exclusive and controlling aspect of extra-territorial power of authoritarian states. This article argues that a consideration of co-occurrence of positive and negative diaspora politics is needed for a holistic understanding of state-led transnationalism and its contested relationship to national territory and popular sovereignty. In this article, we build on the example of Turkish policies, which on the one hand took considerable steps to include its citizens abroad and on the other continued the exclusion of the 'enemies of the state' and re-defined the limits of political membership at home and abroad. By analysing the new diasporic institutional practices, the enfranchisement of external citizens and the right to exit along with loss of citizenship provisions, we show that Turkish state policy disrupts the assumed holy trinity of nation-state-territory forging a de-territorialised unity between internal and external citizens, as well as a de-territorialised division along the lines of party loyalty. Looking at diasporic engagements in all three dimensions - institutional, political and legal- through the lens of citizenship, we demonstrate that they are neither the extension of a heavy handed extra-territorial state power nor of an all-inclusive diaspora policy but a more complex combination of the two.

KEYWORDS: diaspora, citizenship, emigration, transnationalism, authoritarianism, Turkey 


\section{INTRODUCTION}

Research on states' engagement with non-resident citizens has long lagged behind, mainly due to the persistence of identifying international migration in terms of immigration rather than emigration (Collyer 2014:72). While transnationalism scholars have well documented migrants' activities connecting, navigating and spanning different territorial entities since the late 1990s (Glick Schiller et al. 1995; Levitt and Jaworsky 2007), the interest in actions and policies of countries of origin, so called-sending states, has only risen in the last decade. The flourishing literature has sought to catalogue different diaspora policies and explain the 'sudden' increase in states' involvement. For the most part, this scholarship casts statediaspora relations through a positive lens, reading it as a sign to develop and/or maintain links with populations abroad albeit in different ways and at varying degrees (Abramson 2017; Gamlen et al. 2013; Gamlen 2014b; Collyer and Vathi 2007; Lafleur 2011; Palop-Garcia and Pedroza 2017). On the other hand, an adjacent literature on the extra-territorial authoritarian state power (Brand 2006, 2010; Dalmasso et al. 2017; Glasius 2017) calls to shift the gaze 'from the west out' (Dalmasso et al. 2017:1) and to consider the negative side of the same coin, focusing on a variety of mechanisms to extend extraterritorial repression and the ways in which even the mimicking of democratic instruments such as expansion of voting rights bolster control.

Building on these two highly related literatures, and using Turkish state's policy as a case study, we make a twofold analytical argument. First, we suggest that positive-only and negative-only diasporic engagements can explain the story only partially. State-led transnational activities (of authoritarian regimes) may evolve and institutionalise in some respects in line with the global trends of positive diaspora engagement, i.e. extending voting rights to citizens abroad, however they are always embedded in the larger process of transnationalisation of a citizenship regime. Simultaneously, states may engage with their 
citizens abroad in a negative sense which, for example in the current Turkish political climate, is proven by the purge against political opposition that extends well beyond the national borders. However, marking those as extra-territorial authoritarian state practices and accepting the authoritarian nature of the regime as a blanket explanation also offers an incomplete picture as it disregards the co-occurrence of positive engagement practices of the same states. Turkey's recent diaspora governance practices clearly illustrate that state-led diasporic politics may be not black or white but rather a composition of both positive and negative engagements with its populations abroad, ranging from voting rights for all to loss of right to mobility and citizenship for some. As a remedy to partial explanations offered in meticulous studies of positive-only and negative-only diasporic engagements, we suggest looking at this through the citizenship lens, which not only transcends the home-diaspora divide but also helps circumvent the groupism that often surrounds the term diaspora. Following the recent scholarship, we perceive diaspora as a claim for engagement between homeland and current or ex-citizens abroad rather than an entity with clearly defined boundaries of membership (Adamson 2017; Brubaker 2005; Mavroudi 2007). Therefore, we only use the term diasporic for such claims, particularly made by the Turkish state. While some scholars stress that diasporising states' measures apply equally to all members that hold this status (Ragazzi 2014), others draw attention to the discretionary power of states in recognising representativeness of certain actors and distributing resources (Smith 2003). We agree with the latter approach, which lead us to our second argument.

Second, we show how state-led transnationalism, in the form of both negative and positive diaspora engagement, carries important implications for our understanding of political membership, namely citizenship, and popular sovereignty, an aspect that is often shadowed. While citizenship scholars have duly noted the challenges to the national citizenship posed by the movement of people across national borders at different levels, i.e. urban (Holston and Appadurai 1999), global (Held 1995), cosmopolitan (Linklater 1998) or postnational (Soysal 1994), and the increasing trend of dual citizenship that jeopardises the "neat trinity of state 
territory, state authority, and the people' (Faist 2007:3), a relatively stable distinction between internal and external citizens determined by one's territorial position vis-à-vis the country of origin (Bauböck 2009) has been maintained in diaspora studies. However, we show here that contemporary practices of not only 'transmigrants' (Glick Schiller et al. 1995:48), but also a state's diasporic policies, call into question territoriality as the defining character of the internalexternal citizenship distinction. Here we build on Brand's work $(2006,2010,2014)$ on the diaspora engagement of MENA countries, that shows the inextricably linked nature of citizenship struggles at home and abroad, which posit states' diaspora engagements as part and parcel of re-configuration of political membership beyond the outside-inside dichotomy. Relatedly, we join Collyer (2014) in his observation that extra-territorial performance of rights of "the people," as for instance manifested in the growing trend of allocating special representation for external citizens in the home states' parliaments, shifts the sources of legitimacy from territorial state sovereignty to a sort of popular sovereignty that goes beyond the defined territory of the state.

However, the Turkish example works as a litmus test particularly for Collyer's (2014) inquiry as it points at the possible political limits of the notion of popular sovereignty. While the Turkish ruling elite embraces a rhetoric of "popular sovereignty" that goes beyond the state's territorial borders, it does so by overtly equating popular sovereignty with political loyalty to the incumbent government, embodied in the persona of the president. Moreover, the loyal (transnational) Turkish citizens fully enjoy citizenship rights, from voting from afar, to working, investing, travelling in and out of the country freely whereas political dissidents at home and abroad are deprived of, among others, their right to mobility, which forcefully territorialises them. The political and bureaucratic authorities' perception of political opposition as an "existential threat" has been a source of justification for suspension of legal protections and citizenship rights during the two year-long state of emergency (July 2016-July 2018) and will certainly continue with the institutionalisation of the 'exceptional' rule-making under the new presidential system that led to an over-concentration of power at the hands of the president 
without checks and balances. Even though this is clearly related to the deepening authoritarianism in Turkey, the state of exception is an intrinsic character of the modern sovereign powers and, in Agamben's terms, these powers "claim[s] to maintain law in its very suspension" (2005:59). This is well proven by the recent measures introduced against 'the war on terror' in Western states that again make use of the toolkit of legal dimension of citizenship such as deprivation and confiscation of passports (see Joppke 2016; Kapoor and Narkowicz 2018; Skyes 2016). Therefore, we argue that, we need a rather holistic look at institutional, political and legal relations between home states and their external citizens, in order to empirically capture the limits of extra-territorialising citizenship rights, political membership and popular sovereignty.

Our analysis of the Turkish case is based on various forms of data we collected. First, following Fairclough's (2010) approach to discourse as a set of social relations between entities, we did a critical discourse analysis of all issues of Arti90, the three-monthly journal of the Turkish diasporic institution. We studied all sixteen issues published online between January 2012 and December 2016, with due attention to the timing of the topics covered, their salience and position in the journal, as well as the content of those texts closely related to the citizenship rights of citizens abroad. Secondly, we conducted a policy analysis, by collecting parliamentary reports, decrees, laws and regulations pertaining to the rights of external citizens in general and right to exit and enfranchisement in particular. Finally, we compiled official election results abroad since 2007 , the first time when citizens abroad could vote, and, based on a comparative analysis of election results at home and abroad, examined the election results in relation to Turkey's diasporic politics.

In the remainder of this paper, we first unpack the recent studies tackling the emergence of diasporic politics and explain the variations and common patterns. Based on the Turkish case, we show why these innovative contributions do not sufficiently capture the complexity of current diasporic politics on the ground. It is our contention that joining forces with a citizenship 
lens will enrich the toolkit of diaspora studies and help us easily decipher the ways in which seemingly contradictory state practices co-exist at the institutional, political and legal dimensions. To prove our point, we move on to the Turkish case and explore these three dimensions on its own right: the rise of new diasporic institutions, the enfranchisement of external citizenry and the regulations of loss of citizenship and right to exit. Finally, we stress that further studies on diasporic politics must include the span of the co-occurrence of negative and positive diaspora engagement and situate these within the larger processes of deterritorialisation of citizenship, expansion of political membership and shifting popular sovereignty at home and abroad.

\section{DIASPORIC ENGAGEMENTS, EXTERNAL CITIZENSHIP AND LIMITS OF MEMBERSHIP} IN AUTHORITARIAN REGIMES

The fact that countries with different size, economic development and political system have recently begun to develop diaspora policies, which Gamlen (2014b) rightfully calls a global trend, has urged scholars to study state-external citizen relations. Whereas economic (remittances) and political (lobbying) interests maintain significant roles (Bauböck 2003) in states' diaspora engagement, several other factors are underlined, ranging from the impact of emigrant lobbying (Brand 2006, 2014; Escobar 2006), to the evolution of domestic politics (Lafleur 2011), and to the diffusion of norms (Turcu and Urbatsch 2015) and institutions (Delano 2014; Gamlen 2014b; Gamlen et al. 2013). Moreover, while some scholars have put more emphasis on the issue of external voting in an insular way (Collyer and Vathi 2007; Lafleur 2011; Palop-Garcia and Pedroza 2017; Turcu and Urbatsch 2015), others have perceived this as part of the general phenomena of the 'rise' of diaspora engagement of sending states (Brand 2006; Collyer 2014; Delano 2014; Delano and Gamlen 2014; Gamlen 2014a; Pedroza and Palop-Garcia 2017; Ragazzi 2014) or given more attention to the spread of new diaspora institutions and homeland practices (Abramson 2017; Gamlen 2014b; Öktem 2014). Therefore, the scope of these studies has focused first and foremost on the new 
diaspora institutions and external voting rights while they and paid little attention to the implications of diaspora policies for citizenship practices at home and abroad.

External citizenship is distinguished from internal citizenship as "a generic concept that refers to the status, rights and duties of all those who are temporarily or permanently outside the territory of a polity that recognizes them as members." (Bauböck 2009:478). The very act of mobility across territorial borders of a political community makes one an external citizen, and therefore categorically speaking distinguishes external from the internal citizens. An important part of this distinction lies in the right to exit, return, or in short, the right to mobility. Even though international covenants recognize the right to exit irrespective of one's citizenship status (ICCPR Article 12 paragraph 2), this right is neither absolute nor is it uniformly applied in the practice of nation states. There are several examples when states have heavily regulated the right to exit, making it dependent on substantial screening and therefore a significant tool for controlling their populations (i.e. Shapiro 2016 for South Africa, Rozin 2011 for Israel, and in general Brand 2006, 2010, 2014).

While this categorical distinction between internal and external citizens seems intrinsic to the field of diaspora studies and its exclusive focus on non-resident citizens, certain citizenship rights, and particularly the right to mobility as the primary condition to become an external citizen and conditions for maintaining or loss of citizenship, are marginally included in the most comprehensive models (e.g. Palop-Garcia and Pedroza 2017; Pedroza and Palop-Garcia 2017; Ragazzi 2014). Holding that "the global trend is in the opposite direction" (Ragazzi 2014:76), they treat it as 'a thing of the past'. In that sense, there is an emphasis on the institutional and political dimension of state-external citizen relations whereas the legal dimension pertaining to maintaining formal citizenship ties has been overlooked.

This comes particularly to light when one scrutinizes the diasporic policies of authoritarian or hybrid states such as Turkey where diasporic engagement is not necessarily positive and 
positive only. Evidently, this omission has to do with the level of analysis. These studies have taken on the ambitious task of offering comparative classifications (Ragazzi 2014), index of policies (e.g. EMIX by Palop Garcia and Pedroza 2017) and gradations of political inclusion on the basis of electoral rights offered (Palop Garcia and Pedroza 2017). For instance, Ragazzi (2014) develops five typologies of states: the expatriate state that focuses on cultural and educational policies, the closed state that heavily regulates and restricts the mobility of its citizens and does not allow external voting, the global-nation state that represents the broader number of policies and grants most rights, the managed labour state that provides investment schemes, and the indifferent state, which does not really engage with its diaspora in any respect. According to these classifications, Turkey qualifies to be at the inclusive end of the spectrum, namely as a case of "full inclusion" in Palop-Garcia and Pedroza's (2017) model and as a "global-nation" in Ragazzi's (2014) (see also Sahin-Mencütek and Baser 2018). However, our analysis shows that Turkey is a case of full inclusion and a global-nation, only to the external citizens aligned to ruling party ideology and not to those who are critical of it. Hence a case like Turkey points at a puzzle that the existing models of diasporic states cannot yet fully grasp.

This puzzle seems to be picked up by contributors of an adjacent literature focusing entirely on the diaspora engagement of authoritarian states and underlining much more explicitly the negative side of the story. While Collyer and King (2015) show how states through direct, symbolic and imaginative mechanisms seek to extend their control beyond national territories, in their recent intervention in this journal, Dalmasso et al. (2017) claim that inclusion of nonresident citizens in authoritarian regimes can never be understood in the same way as in a democratic setting, as it is always "precarious, conditional both on the exile's good behavior and on the 'whim of the regime'" (Dalmasso et al. 2017:2). They observe a clear difference between authoritarian governance at home and beyond borders and demonstrate the ways in which authoritarian states maintain and develop submissive ties with their populations abroad and, by means of them, gain extraterritorial state power. For example, unlike traditional ways 
of controlling populations, such as imprisonment and censorship, Moss and Michaelsen's (2017) notes on Syria and Iran show how the state can exert control over its external citizens through subjecting the close relatives of critics abroad to (the threat of) arrest, harassment or torture. Moreover, they also question the validity of citizenship as an analytical lens with which to understand the engagement of authoritarian regimes with its 'populations abroad.' In a follow-up article, Glasius (2017:2) argues that instead of treating them as citizens, "the authoritarian state approaches its populations abroad, and includes or excludes them, as subjects to be repressed and extorted, as clients to be co-opted, or as patriots to be discursively manipulated."

These recent contributions have the important function of displaying negative engagements, particularly for authoritarian and/or hybrid cases such as Turkey, a regime that is notoriously drifting to authoritarianism (Akkoyunlu and Öktem 2016; Esen and Gümüscü 2016). Yet we contend that they fall in to the same fallacy as general diaspora engagement studies as they fail to see that authoritarian states' actions are simultaneously and selectively inclusive and exclusive. This complexity is revealed only when we look closely at what happens to the citizenship regime as a whole - at its institutional, political and legal dimensions and particularly to the right to mobility, a precondition for diasporic ties with the home state. Even though we agree with Dalmasso et al (2017:1) that authoritarian states are not "giant prison camps, locking their populations in" and that they have several other tools at hand to extend their extraterritorial power, as also theorised by Collyer and King (2015), the Turkish example shows that not only that some citizens get 'locked in' the territory with very marginalising effects on their lives but also that leaving might mean a complete loss of membership while others, despite being non-resident, enjoy their citizenship rights to the full extent.

Looking at diasporic engagement practices of authoritarian states with a citizenship lens that pays due attention to the seemingly contradictory institutional, political and legal relations 
between home states and their external citizens, would not only allow for detecting cooccurrence of negative and positive engagements of states but also the dynamic demarcation lines through which states are selectively exclusive and inclusive in the definition of the limits of their membership towards their populations abroad and at home. Here Brand's (2006, 2010, 2014) studies on authoritarian and in-transition regimes' engagement with their citizens abroad, offer us a good entry point. In her book that analyzes the diaspora institutions of four MENA countries (Morocco, Tunisia, Lebanon and Jordan), Brand (2006) establishes a strong relationship between a state's diasporic engagement and sovereignty and captures the broader implications for the limits of political membership. While in her 2010 study that focuses on the extension of extra-territorial voting rights, Brand is critical of perceiving such seemingly democratizing moves as expansion of citizenship rights - despite the adoption of citizenship language - following the Arab uprisings, she (2014) contends that the depth of the transition at home will circumscribe the re-drawing of citizenship regimes through extension of voting rights. Importantly, Brand $(2006,2010,2014)$ consistently demonstrates that states' treatment of its populations abroad should be understood as part and parcel of not only negotiations over new forms of political membership but also of prevailing citizenship struggles at home. While Brand therefore takes the citizenship regimes as interconnected at home and abroad, her analysis presumes that these regimes are either positive or negative for all, which we show is not always the case.

Last but not least, we argue that our analytical framework reveals the limits of the relationship between expansion of extra-territorial political membership and popular sovereignty. Based on a global survey of electoral systems, Collyer (2014:67) inquires the implications of introduction of external voting on the relationship between democracy, sovereignty and nation, and argues that extending political membership to non-resident citizens may not lead to drastic changes in territorial sovereignty of neither sending nor host states. Yet they usher in a new relationship of political authority to territory as the political authority begins to gain legitimacy through popular sovereignty which, with external voting rights, has expanded beyond territorial 
borders of nation-states and gained symbolic significance. In Collyer's words (2014:71) "The symbolic source of their sovereignty is thereby partially displaced from control over territory to the legitimacy they derive from representing the nation."

Our analytical framework builds on Collyer's take on the symbolic significance of enfranchisement for the legitimacy of the state authority and the ensuing disarticulation between nation and state in territorial terms. Yet, we contend that when we consider states' diasporic engagement in the institutional and political dimensions, together with the transformations in the citizenship laws, namely the legal dimension, we may observe an even narrower definition of 'the people' in and by whom the legitimacy of the political authority is founded. The Turkish example clearly shows us that while the ruling party needs and gains consent of (enough) voters both at home and abroad for legitimacy, the political membership of both internal and external citizens remains conditional upon their act of support for the ruling party that legitimises its power through elections, regardless of their unfair nature, which qualifies it as a competitive authoritarian state (see Esen and Gümüscü 2016 on this). This is evident in the way the extra-territorial performance of popular sovereignty is balanced out with the curtailment of another pillar of citizenship, namely the right to mobility, of political dissidents who do not give consent to the ruling party.

What also emerges as significant in the Turkish case is the amalgamation of the ruling party and state as an actor that does not neatly fit in to the distinction developed in the literature between state and party outreach to populations abroad (Burgess 2018; Koinova 2018; Østergaard-Nielsen and Ciornei forthcoming). While Turkey could be considered a typical case of state outreach, according to Burgess (2018), that is characterised by official state agencies and weak institutionalisation of political parties abroad, the outcomes of diaspora engagement are in line with what is expected from party outreach, that is, high turnout in elections as well as "export of dysfunctional partisanship to transnational spaces" (Burgess 2018:374). Therefore, since in the Turkish case the ruling party AKP has 'conquered' the state 
(Somer 2017), the state-led outreach then easily controls and uses all the institutional, political and legal tools in its vicinity to shape what appears as an expansion of "popular sovereignty" beyond territorial borders by fully including AKP supporters and partially excluding dissidents in terms of their enjoyment of citizenship rights.

Hence, we argue for a holistic citizenship lens that gives less weight on the territorial distinction between internal and external citizens by embedding a state's diasporic engagement within its citizenship regime and that considers extra-territorial state power as a manifestation of state-citizen relations at institutional, political and legal dimensions.

\section{TURKISH STATE'S ENGAGEMENT WITH EXTERNAL CITIZENS}

Turkish diasporic politics have evolved and taken conflicting turns over the course of the diasporisation process, which, as Abramson (2017) shows in the case of Israel, entails the creation of an embodied and emotional homeland. The state-led transnationalism and political ties between diasporic communities with the Turkish homeland have received widespread scholarly attention (e.g. Aksel 2014; Aydin 2014; Mügge 2012; Okyay 2015; ØstergaardNielsen 2003; Öktem 2014; Sahin-Mencütek and Erdogan 2015; Sahin-Mencütek and Baser 2018). This growing body of literature builds on the broader trends in diaspora literature, namely the establishment of the new diaspora institutions and the enfranchisement of external citizens through facilities of voting in the countries of residence. This scholarship has also been critical in displaying the selectively exclusive character of the current diaspora policy of the AKP when it comes to some diasporic communities, namely Kurdish, Alevi or Assyrian migrants (e.g. Østergaard- Nielsen 2003; Sahin-Mencütek and Baser 2018). However, implications of the co-occurrence of inclusive and exclusive policies for political membership in Turkey have so far not been examined. Nor have the parallels between this kind of exclusion 
towards some citizens abroad and the increasing chasm between Turkish state and different citizen groups at home.

\section{Diasporic Institutions: From Limited to Selective Inclusion}

Unlike earlier decades, Turkey's engagement with citizens abroad has become of paramount importance concomitant with the shift towards a proactive foreign policy in the late 1990s and 2000s (Aydin 2014; Öktem 2014). While the initial engagements were a response to the pressing needs of the emigrant communities and national and religious education of the children of emigrants which were serious concerns for almost all governments (Okyay 2015), the new diasporic institutions of the 2000s are designed to construct a diasporic identity strongly tied with an imagined Turkish homeland.

Before the first official diaspora agency, the Turkish state established ties with emigrants through a network of mosques linked with Turkish Directorate for Religious Affairs (Diyanet) founded in several European states. This was also meant as a counter response to the Islamic and anti-Kemalist movements, which were suppressed in Turkey yet freely active in Europe, following the 1980 coup (see Senay 2012 for 'trans-Kemalism', the secularist founding principles of republic and its related diaspora policies). Through the Turkish Cooperation and Coordination Agency (TIKA), founded in 1991, and 'Coordination Councils', established within diplomatic representations in 1986-1987, regular and formal diasporic relations were developed and later carried on to the Consultation Commission for Citizens Living Abroad (Yurtdışında Yaşayan Vatandaşlar Danışma Kurulu, YYVDK), founded in 1998. Members of these commissions were appointed by the government from among the "approved expatriate organisations database of the Ministry of Interior" with the goal to unite the expatriate force against host-country political actors' manoeuvres that contested Turkey's officially held 
stances in issues such as Armenian genocide, PKK or Cyprus Conflict (Okyay 2015; Østergaard- Nielsen 2003).

The official diaspora discourse of the AKP rule in early 2000s was interpreted as more inclusive than the previous decades (Aydin 2014; Okyay 2015; Öktem 2014). The diasporarelated state institutions have diversified and expanded their focus, scope and budget with the establishment of Presidency of Expatriate Turks and Related Communities (Yurtdışı Türkler ve Akraba Topluluklar Başkanlığı, henceforth YTB) as the flagship agency of Turkey's new diaspora policy in 2010. The agency is focused mainly on three groups; labour migrant communities and their descendants living abroad, kin or related communities in the Balkans and Central Asia, and foreign, often Muslim students on YTB scholarship who are expected to build ties with Turkey and develop them further after returning to their countries of origin.

YTB's three-monthly journal titled Arti90 (Plus 90, referring to Turkey's international telephone code $)^{i}$ represents the "very wide range of diaspora communities", and as Öktem (2014:14) aptly puts, "the challenges to an operationalisation of diaspora policies." Indeed, a close reading of the journal's all 16 issues published between 2012 and 2016 reveals that the motivations and goals of the agency are explained in every editorial with an emphasis on the strength of "new Turkey." This populist rhetoric is developed and widely used by the AKP during election campaigns of 2010 s to refer to its rule as "the golden era of single-party governments, stability, inclusion, and advanced democracy" (Selcuk 2016:577). Evidently, this reference to "new Turkey" that external citizens can rely upon is not coincidental nor is the cover of the 5th issue with a picture of Erdogan waving hand in the background of European country flags and with the caption that says "You are never and ever alone!: YTB's story of foundation" (Issue 5, 2013)." Although the life stories of students, covered in each issue, are from all over the world, each issue has a special theme generally related to the emigrants in Europe, namely discrimination and racism in Western Europe, assimilation and adoption of 
immigrant children in Europe. In that sense, it shows continuity with diasporic politics of earlier decades that selectively defined and addressed the needs of diasporic communities.

Despite its initial discursive claims for diversity and inclusiveness, once one traces them over time, YTB's activities in general reveal continuity with past practices of selective engagement with certain segments of external citizens who form AKP's electoral base abroad. Take, for example, the Turkish - Co-ethnic and Kin Communities Meeting (Türk - Soydaş ve Akraba Toplulukları Buluşması) that was held in Istanbul in February 2010. Among the 2500 representatives that participated in the meeting, those who were given voice were expatriates in Europe and the US, co-ethnics and/or fellow Muslims and co-ethnic immigrant associations, whereas Kurdish and Alevi associations abroad were not contacted or invited on this or other occasions (Okyay 2015). Another example of continuity is the revival of the YYVDK of 1990s under YTB's roof in 2012 as the "Consultation Commission of Citizens Abroad" (Yurtdışı Vatandaşlar Danışma Kurulu, YVDK). Just as its predecessor, the YVDK was again formed by appointment, this time by AKP government, and clearly reflected an ethno-religious bias as the members were businesspeople and representatives from civil society organisations mainly working on issues related to Islam and Turkish-language teaching in their countries of residence (for the full list of members, see Arti90, Issue 5). The inclusion of representatives from organisations driven with the bond of Muslim brotherhood, such as the IGMG (Islamische Gemeinschaft Milli Görüş) and overseas MÜSIAD (Independent Industrialists' and Businessmen's Association), illustrates a reversal of the official secularist selection bias of the 1990s 'trans-Kemalism' (Senay 2012). Yet it also reproduces the exclusionary logic of favouring like-minded agents.

In the last years, rising polarisation in domestic politics certainly has widened the gap between different diasporic communities and the Turkish state. Gezi Park protests during May-June 2013 sparked a nation-wide uprising and were carried forward with street protests and 
neighbourhood forums in many cities of Turkey against rising authoritarianism. It also found resonance among Turkish citizens abroad. Formerly distinct diasporic groups and individuals with different ideological backgrounds came together first time in sit-ins and demonstrations that were organised in many capitals around the world and have mobilised in social media to show solidarity with the protestors in Turkey (Baser 2015; Giglou et al. 2018). The politicisation and polarisation among external, as well as internal citizens, got a new twist as of December 2013 with the de facto end of the close alliance between AKP and the transnational Gülen movement, that is the Islamist political and social movement active all over the world for more than two decades now, and was one of the main political and economic support base of the AKP (see Tas 2017 for more on this). None of these political contestations were mentioned in YTB's journal Arti90 which at that time continued to cover only positive ties between the Turkish state and the 'diaspora' and focus only on the crucial function that YTB accomplishes in generating one cohesive Turkish diasporic identity, devoid of internal conflicts.

The domestic-diasporic politics divide seems to be put aside with the July 15, 2016 failed coup attempt which marked new heights in the way Turkish state sees its citizens abroad as friends or enemies of the state. Arti90's last two issues, which came out in the immediate aftermath of July 2016, made bold criticisms towards European governments for their unwillingness to cooperate with Turkish government in their "fight against FETO" (short for "terrorist organisation' of Fethullah Gülen, the leader of Gülen movement) and called the 'diaspora' to raise their voices to unmask the real face of Gülen movement in their countries of residence. This proved how the new diasporic institution, YTB, was instrumentally used for the government's positive yet selective engagement attempts with external citizens when the need arises to form a public opinion abroad in line with Turkey's (read AKP's) official discourse.

Despite these initial reactions and attempts to mobilise external citizens, no new issue of Arti90 came out in 2017. This is perhaps a residue of the two year-long state of emergency that lasted until July 2018 , and the recent political stagnation in Turkey which brought many media 
outlets, government-led or otherwise, to be put on hold. The same goes for the activities of YTB's consultation commission YVDK which is no longer active.iii This excitement of the early 2010s and the current suspension reveals that state-external citizen relations cannot be conceptualised without consideration of the political frictions and state-citizen relations at home.

In sum, the new diasporic institutions developed during the AKP period stand in stark contrast to the weak ties of the earlier decades in institutional terms. However, along with previous studies' findings on Turkey's state-led transnationalism, the evolution of the YTB's narrative reveals that the strong ties that these new institutionalized practices aimed to cultivate were at best selectively inclusive and reproduced a bias similar to the initial attempts of the 1990s nationalist governments. They also contributed to a discursive shift towards popular sovereignty with a new Turkish state under the leadership of Erdogan that protects resident and non-resident citizens alike. All in all, Turkey's diaspora policies in 2010 s follow the global trend of expanding diaspora governance, yet just moved the bar from limited to selective inclusion in institutional terms. These positive institutional engagements do not fit squarely in the inclusive camp, identified in Palop Garcia and Pedroza's (2017) and Ragazzi's (2014) studies, and are closer to Dalmasso et al.'s (2017) point that they are conditional upon the good behavior of the external citizens. While the next section shows that the political arena opens up to all external citizens albeit the selective inclusion in institutional engagements, the last section on legal dimension again swings the pendulum of inclusion to the condition of good behavior.

\section{Enfranchisement of External Citizens: Political Inclusion of All at the Ballot Box}

The recent changes in the procedures to vote abroad has the effect of expanding legitimate basis for popular sovereignty from “inside-out," in Collyer's (2014) terms, allowing inclusion of 
all at the ballot box. However, this led to a mere reflection of increasingly polarizing politics of the AKP in the external citizens' voting preferences and extra-territorial political participation, which is shaped along the lines of loyalty/dissident to the existing political regime.

Until 2012, the enfranchisement of citizens abroad was not explicitly regulated, therefore suffering from the enactment and regulation gap pointed out by Palop-Garcia and Pedroza (2017). The right of voting at the polling stations at the borders was first introduced in 1987 but did not receive constitutional legitimacy until the 1995 amendment of the Art. 67 of the constitution. The 1995-2008 period is characterized by inertia with no further steps to mobilise external citizens aside from providing polling stations at the customs. What's more, the possibility to vote only at the Turkish customs resulted in the practice of this political right only when external citizens travelled to Turkey, hence, even if temporarily, were within the territorial borders and jurisdiction of the Turkish state. The 2008 amendment to the Law on Elections and Electoral Registers (Art. 94/A) radically changed this and introduced three other methods of voting besides the ballots at the Turkish customs: by regular mail, at the representations abroad and electronically. A final amendment in 2012 to the Law on Elections and Electoral Registers regulated the practical aspects of overseas voting procedures. This moved Turkey in the direction of a "full inclusion" country, again following Palop-Garcia and Pedroza (2017).

The first elections to be organized in the overseas representations were the August 2014 presidential elections which was also the first presidential election in Turkey's political history. This was then followed by the June 2015 parliamentary and November 2015 snap elections, the April 2017 constitutional referendum as well as the most recent June 2018 presidential and parliamentary elections. Therefore, after its authorisation, the voting rights of external citizens have been put to test very frequently. The increasing turnout and results of the elections abroad reveal not only a blurriness of the distinction between internal and external 
citizens in terms of their political participation but also an ongoing process of extraterritorialisation of the political divisions along party lines.

Table 1. Turnout Rates in Turkish Elections Abroad*

\begin{tabular}{|l|l|l|l|}
\hline & $\begin{array}{l}\text { Turnout at the } \\
\text { borders }\end{array}$ & $\begin{array}{l}\text { Turnout at the } \\
\text { representations }\end{array}$ & $\begin{array}{l}\text { Total turnout } \\
\text { abroad }\end{array}$ \\
\hline 2007 General Elections & 8.88 & N/A & 8.88 \\
\hline 2010 Referendum & 7.68 & N/A & 7.68 \\
\hline 2011 General Elections & 5.03 & N/A & 5.03 \\
\hline 2014 Presidential Elections & 10.6 & 8.3 & 18.9 \\
\hline 2015 June General Elections & 4.34 & 32.5 & 36.84 \\
\hline 2015 November General Elections & 4.78 & 40.01 & 44.79 \\
\hline 2017 Referendum & 3.3 & 44.6 & 47.9 \\
\hline $\begin{array}{l}2018 \text { June General and Presidential } \\
\text { Elections }\end{array}$ & 5.45 & 44.88 & 50.33 \\
\hline
\end{tabular}

${ }^{*}$ All figures presented are percentages.

Source: Authors' calculation based on YSK website.

Despite having a low start with the 2014 presidential elections, the turnout rate abroad consistently increased in every election reaching $50 \%$. The rise in absolute numbers is also nothing short of impressive. The twelfth issue of Arti90 in 2015 shows that since its first introduction in 1987 when some 47,000 went to the polls at the customs, the number rose almost thirty times in 2017 reaching almost 1.3 million voters (Issue 12, 2015). Therefore, it seems that the political engagement with external citizens through enfranchisement, resonated well with a significant portion of the diasporic communities.

Clearly, some institutional interventions in the implementation of the election law have assisted in the rise of turnout (e.g. facilitation of voting and registration procedures, extension of time period of elections and, since 2017 public referendum, the possibility to vote in any consulate). However, most important of all is the increasing electoral mobilisation through state and party channels. This is where the inclusion pendulum which came close to full inclusion on the 
political dimension - with the right to vote for all - made a swing back to selective inclusion due to these institutional interventions that favoured pro-AKP electorate abroad.

YTB, as the official diasporic institution, engaged in mobilising its audience. For instance, the ninth issue of Arti90, which was published in July 2014, was dominated by the topic of presidential elections, the tenth issue of Arti90 came out in June 2015 with the title "Are you up for Turkey? 28 million voters will go to the ballots in 54 countries" (Issue 10, 2015). The following issues of Arti90 were also actively used as a milieu to communicate the procedures for voting abroad, explaining in detail the efforts of YTB personnel in reaching out to voters to increase the turn outs and give the results from the ballots abroad and at the customs (Issue 11, 2015 and Issue 12, 2015). Moreover, Arti90 was not always neutral in its extensive coverage of voting rights of the external citizens, as a state medium would be expected to be. Upcoming elections were in the headlines in four out of sixteen issues and the right to vote was mentioned as one of the longstanding wishes of the external citizens and a necessary step for the excellence of Turkish democracy in almost every issue, either at the introductory pieces penned by the editor and the head of the YTB or by the political figure interviewed for each journal issue. Nonetheless, the then prime minister Erdoğan's role was highlighted and his personal initiative for the establishment of YTB which "ended the 50 years of negligence towards our citizens" was underlined every time the 2012-dated amendments to the election law were mentioned. The subtext to the storyline is that this regulation, which makes voting abroad practically possible, was realized thanks to the AKP and specifically Erdoğan's leadership. Therefore, as we have seen on the institutional dimension, on the political dimension too the limits of membership have been expanded and a shift towards extraterritorialised popular sovereignty has been promoted in exchange for gratefulness to the ruling party. A case in point is the article written by the director of YTB Kudret Bülbül in the ninth issue of Arti90, right before the 2014 presidential election at which PM Erdoğan was a candidate: 
As mentioned earlier, our citizens living abroad were disregarded and abandoned for 50 years. To compensate for this mistake, YTB was founded in 2010 (...) Our citizens' ability to vote wherever they are, their political participation and the attention the presidential candidates show towards them (also the attention that will be shown in future elections) are processes that will naturally lift the disregard [of the past]. (Yurtdışında Yerinde Oy Kullanmanın Anlamı [The meaning of voting where you are], by Assoc Prof. Kudret Bülbül, July 2014: 18-19). iv

While referring to presidential candidates in the plural could be seen as an acknowledgement of the existence of other candidates, his further analysis of possible election results leaves the readership with the impression that there is no alternative for conservative voters, other than the self-proven leadership of Erdoğan. Aside from utilisation of YTB, starting with the November 2015 snap elections, AKP did not abstain from using consulate address databases to send campaigning material that took credit for the recent diasporic engagements such as the YTB or decreased flight costs of Turkish Airlines. The leaflet with AKP logo posted to external citizens' home addresses before the April 2017 constitutional referendum made an open call for a "yes" vote for a "stronger Turkey" and an "effective fight against terror," particularly "FETO" next to the timetable for shuttle services to the consulates on election days. With developments as such, not only the ever-thinner line between party politics and state politics evaporates but also the diasporic relations between the home state-external citizens are cast in terms of relations with AKP and Erdoğan.

Aside from using official state channels for propaganda, AKP also relied on non-state actors such as mosque associations and pro-AKP organisations, such as the Cologne-based Union of European Turkish Democrats (UETD), the headquarters of which was opened by the then PM Erdoğan, which has become the interlocutor between the AKP and its overseas constituency. Opposition parties' representatives, and both established and new civil society 
initiatives abroad, which have emerged in the aftermath of the Gezi uprisings, have also taken part in political outreach activities such as organizing rallies, campaign trips, and sending out hand-outs (Abadan-Unat et al. 2014). However, their presence remained relatively weak, due to the lack of established party organs, limited resources and partial attitude of state channels, which created an uneven playing field characteristic of competitive authoritarian regimes just like at home (Esen and Gümüscü 2016).

The voting results presented in the table 2 show precisely that: not only that the polarisation at home found strong resonance among the voters abroad, but also that such transnational campaigning built on the existing political mobilisations (see Burgess 2018, ØstergaardNielsen and Ciornei forthcoming), which gradually attracted the previously disengaged conservative electorate, playing in favour of AKP.

Table 2. Turkish Elections Results Abroad and at Home*

Presidential Elections

\begin{tabular}{|c|c|c|c|c|c|c|c|c|}
\hline \multirow[t]{3}{*}{ : } & \multicolumn{2}{|c|}{$\begin{array}{l}\text { R. Tayyip Erdoğan } \\
\text { AKP's candidate }\end{array}$} & \multicolumn{2}{|c|}{$\begin{array}{l}\text { Eklemeddin } \\
\text { Ihsanoğlu } \\
\text { CHP and MHP's } \\
\text { candidate }\end{array}$} & \multicolumn{2}{|c|}{$\begin{array}{l}\text { Selahattin Demirtaş } \\
\text { HDP's candidate }\end{array}$} & & \\
\hline & Domestic & Abroad & Domestic & Abroad & Domestic & Abroad & & \\
\hline & 51.65 & 62.30 & 38.57 & 27.92 & 9.78 & 9.78 & & \\
\hline \multirow{3}{*}{$\stackrel{\infty}{\circ}$} & \multicolumn{2}{|c|}{$\begin{array}{l}\text { R. Tayyip Erdoğan } \\
\text { AKP and MHP's } \\
\text { candidate }\end{array}$} & \multicolumn{2}{|c|}{$\begin{array}{l}\text { Muharrem Ince } \\
\text { CHP's candidate }\end{array}$} & \multicolumn{2}{|c|}{$\begin{array}{l}\text { Selahattin Demirtaş } \\
\text { HDP's candidate }\end{array}$} & \multicolumn{2}{|c|}{$\begin{array}{l}\text { Meral Aksener } \\
\text { IYI Party's } \\
\text { candidate }\end{array}$} \\
\hline & Domestic & Abroad & Domestic & Abroad & Domestic & Abroad & Domestic & Abroad \\
\hline & 52.43 & 59.37 & 30.76 & 25.78 & 8.30 & 11.04 & 7.41 & 2.99 \\
\hline
\end{tabular}

General Elections**

\begin{tabular}{|c|c|c|c|c|c|c|c|c|}
\hline \multirow{2}{*}{$\begin{array}{l}\text { Political } \\
\text { parties / } \\
\text { Elections }\end{array}$} & \multicolumn{2}{|l|}{ AKP } & \multicolumn{2}{|l|}{$\mathrm{CHP}$} & \multicolumn{2}{|l|}{ HDP } & \multicolumn{2}{|l|}{ MHP } \\
\hline & Domestic & Abroad & Domestic & Abroad & Domestic & Abroad & Domestic & Abroad \\
\hline 空 号 & 40.66 & 50.30 & 25.13 & 15.93 & 12.96 & 21.43 & 16.45 & 9.09 \\
\hline
\end{tabular}




\begin{tabular}{|c|c|c|c|c|c|c|c|c|}
\hline 을 융 & 49.32 & 56.38 & 25.56 & 15.44 & 10.56 & 19.17 & 12.03 & 7.06 \\
\hline 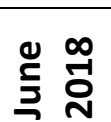 & 41.62 & 51.89 & 22.64 & 16.54 & 11.48 & 17.93 & 10.98 & 7.86 \\
\hline
\end{tabular}

2017 Referendum

\begin{tabular}{|l|l|l|l|}
\hline \multicolumn{2}{|l|}{ NO vote } & \multicolumn{2}{l|}{ YES vote } \\
\hline Domestic & Abroad & Domestic & Abroad \\
\hline 48.76 & 40.54 & 51.24 & 59.46 \\
\hline
\end{tabular}

${ }^{*}$ All presented figures are percentages.

HDP: Peoples' Democratic Party, umbrella party for leftist and Kurdish voters.

CHP: Republican People's Party, the first political party of republican era, loyal to Kemalist founding principles.

MHP: Nationalist Movement Party, right of centre and openly ally with AKP since failed coup attempt.

AKP: Justice and Development Party, right of centre neoliberal alliance, in government since 2002.

IP: Good Party, a new center right party, split from MHP and formed in October 2017.

**In June 2018, two alliances were formed: 1) AKP and MHP and 2) CHP, IYI Party and SP (religious conservative right). The percentages are calculated on the basis of party votes, and not alliances.

Source: Authors' calculation based on YSK website.

On the political dimension, the enfranchisement of external citizenry resulted in the inclusion of all citizens erasing the distinction between internal and external citizens in terms of voting rights, however it simultaneously brought forward a de-territorialized distinction based on loyalty to homeland party politics. While turn out rates and mobilization can be interpreted as positive engagement with homeland politics and expansion of popular sovereignty beyond territorial borders, recent changes in citizenship policies, shown in the next section, hint at a more direct and intentional negative engagement with citizens abroad on the legal dimension which is an extension of the struggles of the political opposition at home. Hence the curtailment of the citizenship rights of all opposing views also blurs the internal-external citizenship distinction, yet from the complete opposite angle of the political inclusion of all through enfranchisement, that is the total exclusion of opposition abroad and at home.

\section{Citizenship Policies: Legal Exclusion of Disobedience at Home and Abroad}


In a strictly legal sense, citizenship is the primary formal tie between states and populations under their jurisdiction and as explained earlier, the regulation of citizenship as formal/legal membership and more specifically the right to mobility touches to the very core of home stateemigrant relations. The Turkish constitution recognises the right to leave as a fundamental right and stipulates that citizens shall not be expelled, nor shall they be banned from entering the country. While in principle Turkish law respects every citizens' right to become an external citizen by enjoying their related right to mobility and allows for the continuation of the citizenship bond with external citizens in Bauböck's (2009) terms, it also maintains that right to mobility can be limited in cases of investigation or prosecution, which need to be determined by judicial bodies (Art. 23).

Since 1981, Turkey also allows dual citizenship for persons who have informed the authorities about their intention to acquire a second citizenship (Kadirbeyoglu 2007). Turkish citizenship law has gradually taken extensive steps to ensure that its populations abroad legally remain as citizens; by not granting renunciation in cases of statelessness (Art.26), by removing residency criteria for re-acquisition for those who received a renunciation permit (Art. 13). To maintain its relationship with external citizens even in the absence of formal citizenship status, Turkey also introduced in 1995 a so-called 'blue card' scheme, which is a privileged noncitizen status that entitles holders to a number of substantial rights in Turkey - such as residence, inheritance and property - with the exception of voting rights.

Moreover, Turkish state also eliminated two major grounds for withdrawal of citizenship in 2009 amendments to the citizenship law, namely the failure to declare the acquisition of foreign citizenship and failure to serve in the military. This left three grounds for the withdrawal of citizenship, all of which are treason or disloyalty related and require the person to be an external citizen in the first place (Art. 29). Former citizens who lose their Turkish citizenship can re-acquire after three years of residence if they do not constitute a threat to national 
security. A more serious form of withdrawal, which did not allow for re-acquisition, was introduced in the aftermath of the 1980 military coup through two amendments to the citizenship law (Art 25 (g) for the citizens by birth and Art 26 for citizens who acquired their citizenship after birth). Very close in their formulations, these provisions allowed the state to withdraw citizenship if the person had engaged in criminal activities against the internal or external security and financial or economic safety of the state while being abroad or went abroad hindering the criminal investigation. In cases of state of emergency or of war the duration could be reduced to one month. According to the report of the Turkish parliament's commission on investigating military coups, after the military coup of 12 September 1980 , Turkey has made generous use of this provision by retrieving the citizenship of 14,000 people while 30,000 people applied for asylum abroad, which included activists, politicians, intellectuals and artists, whom were then involved in different leftist political circles, Alevi and Kurdish associations abroad. ${ }^{\vee}$ Whereas Art. 26 was repealed in 2009, Art. 25 (g) was already removed with a 1992 amendment that also opened possibilities of re-acquisition of citizenship as well as reinstatement of the confiscated property.

Removing these provisions did not mean that those former citizens who lost their citizenship soon after 1981, were automatically granted citizenship, however in line with its increasing positive engagement with its external citizens, AKP government has encouraged them to return to Turkey. In a rally hold in Düsseldorf in 2011, Erdoğan himself uttered these words:

"We invite our artists and writers who had to migrate to Europe because of the obstacles before freedom of expression back to their country. We invite our artists to participate in and contribute to the transformation that Turkey is undergoing. I would like to remind them the door is wide open to them". vi

These statements were also echoed by the then Vice President Bekir Bozdağ who announced that as a government they were ready to grant citizenship to the thousands of people who had 
unfairly lost their citizenship if they were to apply. He reclaimed "These are our people. Our door is open". vii

Now, 25 years after the removal of such a withdrawal ground and almost 40 years after its intensive application, the Turkish state reintroduced a similar withdrawal clause in January 2017 with the governmental decree (KHK 680) that amended the Art 29 of the Turkish citizenship law. This decree is one of many rounds of decrees issued during two-year long state of emergency announced soon after the 2016 failed coup attempt. The Decree no. 680 provides for the withdrawal of citizenship of individuals who are under investigation or prosecution for "breaking the unity of the state and the integrity of the nation", for "violating the constitution", for "armed attack and assassination of the president", for "crimes against the legislative body", for "crimes against the government," for "armed rebellion against the government," for "membership in an armed terror organisation" or for "provision of weapons to armed terrorist organisations" (Turkish Penal Code Articles 302, 309, 310, 311, 312, 313, $314,315)$ if they do not respond to a call to return to Turkey within three months. So far, two lists that include the names of 130 people in June 2017 and of 99 people in September 2017 have been issued by the government. The lists include not surprisingly the name of Fethullah Gülen, who is accused by the Turkish state to have plotted the July 2016 coup attempt. However, the list also includes pro-Kurdish and left-wing People's Democratic Party (HDP) deputies. At first glance, this form of negative engagement with external citizens, even though not unprecedented in Turkish history, seems in sharp contrast with the acts of positive engagement that AKP government has so far undertaken. However, in reality, this follows a continuous line that is also followed on the institutional dimension, manifested in the absence of contact with the Kurdish and Alevi diasporic organisations.

Next to the withdrawal of citizenship, in the immediate aftermath of the July 2016 coup attempt, AKP government also issued a widespread ban on leaving the country for public sector 
personnel, including academics. Although the general ban is now lifted, Turkey still applies discretionary power over its citizens' right to exit. The Decree no. 667 of July 2016 provides for the cancellation of the passports of individuals who are investigated or prosecuted for charges of membership or connection to terrorist organisations or other groups that are a threat to national security. Similarly, the Decree no. 673 in September 2017 provides for the cancelation of the passports of the spouses of people whose passports are cancelled although it contradicts with Art. 30 of the citizenship law which postulates that citizenship withdrawals are personal and do not apply to the children and spouses. This decree certainly casts doubt on the individuality of the citizenship bond and, as it is often used to 'retaliate' the person who is sought after, emerges as a very close account to the Moss and Michaelsen's (2017) notes on Syria and Iran and an example of what Dalmasso et al (2017) calls the "whim of the regime." One widely-known case is Can Dündar, a Turkish journalist who was arrested on charges of being a member of a terror organisation, espionage and revealing confidential documents. Shortly after his release from detention, he fled to Germany and later got sentenced to five years in prison for revealing state secrets. He is one of the many for whom Turkey issued an arrest warrant in his name and requested extradition from Germany. viii While he has 'officially' become an external citizen, in order to force him to return his wife's passport has been cancelled. The situation is however far beyond the 'famous' cases. The government itself announced in December 2017 that 234,419 passports were cancelled in the fight against FETO, which includes a wide range of civil servants, from teachers and academics to law enforcement. ${ }^{i x}$

Again, this is not extremely unusual in Turkish politics, after the 1980 coup, 388,000 persons were denied a passport. ${ }^{\times}$What makes the current practice remarkable is the sharp contrast of such legal exclusion with the measures introduced over the last decade that broadened the limits of the political membership and rendered institutional expansion selectively inclusive. On the other hand, it equally, if not more, contributes to shifting the locus of popular 
sovereignty from territoriality to loyalty to incumbent government since external citizens can enjoy right to vote only in the absence of a threat of loss of citizenship.

\section{CONCLUDING REMARKS}

This paper aimed to contribute to the emerging literature on the growing trend of states' diasporic engagements and the adjacent studies on the extra-territorial power of authoritarian states through the case study of Turkey. Pinpointing the limitations of focusing on negativeonly or positive-only diaspora engagements, we argued that state-diaspora relations are better conceptualised through a citizenship lens that allows tracing parallel processes to citizens at home and abroad. At the genesis of this conceptual argument is the empirical observation of the misfit of the Turkish case, which, according to the elaborate classifications developed in the literature, is (mis)placed at the inclusive end of the spectrum (Palop-Garcia and Pedroza 2017; Ragazzi 2014). This left us with a puzzle to explain; a puzzle that displays contradicting state policies: simultaneously a policy that includes external citizens at different degrees by broadening the limits of political membership through enfranchisement and designing new institutions appealing to the 'de-territorialised nation'; exclude some external as well as internal citizens along the lines of loyalty to the ruling political party, and thus decrease the territorially determined distinction between internal and external citizens. Here we suggest that the puzzle could be solved by considering the diasporic engagement practices that simultaneously occur on different dimensions, namely institutional, political and legal with a citizenship lens. Such a lens allows us to capture the scope of inclusive or exclusiveness of diasporic policies in each dimension and place them within the larger processes of broadening political membership and shifting limits of popular sovereignty. 
Our analysis of the evolution of Turkey's diasporic policies on institutional, political and legal dimensions shows that there has been a shift from indifference to engagement but also clear continuity in terms of institutional engagement as in selectively engaging with like-minded constituencies, only with a stronger ethno-religious undertone. On the political dimension, against the background of the rising suspicion against the external as well as internal citizens with the 2016 failed coup attempt and the ensuing state of emergency, the strategy of the incumbent AKP party/ state has been to increase the number of voting stations abroad during the elections marathon of the last years and at the same time reach out the external potential AKP voter base through available state and non-state channels even by breaching diplomatic manners. ${ }^{\mathrm{xi}}$ While enjoying the right to vote seems to bring external and internal citizens on equal footing on the political dimension -with all the limitations that come with unfair elections in a competitive authoritarian regime- it also nurtured a new dividing line that crosscuts internal and external citizens alike based on loyalty to the AKP's political regime. This new demarcation line that re-defines political membership on the basis of party loyalty and expands the symbolic source of sovereignty beyond the territorial borders of the state was further exacerbated by the recent decrees that suspend the right to mobility of some citizens. Even though the decrees allowing such legal exclusion were enacted during the two-year state of emergency that ended in July 2018 and could therefore be seen as the products of these exceptional times, there is no plausible reason to believe that the current authoritarian regime sealed with April 2017 constitutional change will move in the direction of expanding citizenship rights for all. It should also be remembered that such curtailment of citizenship rights for the proclaimed 'enemies of the state' (e.g. ethno-religious minorities, Kurds and leftists) is no exception in Turkish politics. What is new now is the co-occurrence of expansion on political dimension along with curtailment of rights on legal dimension.

The dynamic citizenship lens, which requires to have a holistic look at institutional, political and legal dimensions of inclusion and exclusion at home and abroad, questions not only the inside-outside dichotomy, but also the very existence of a static "inside" that would expand 
beyond the territorial borders. Recent studies hint at the differences between state and party outreach to populations abroad (Burgess 2018; Østergaard-Nielsen and Ciornei forthcoming) which begs further investigation of the implications of such a divergence for the notions of political membership and popular sovereignty. A dynamic citizenship lens might be particularly useful to study this state-party relationship, especially in authoritarian settings, like Turkey with long years of uninterrupted single party rule, but the idea of a 'unitary sending state' is increasingly problematised in different contexts (see Koinova and Tsourapas 2018). As noted earlier, recent measures introduced as part of 'the war on terror' in Western states demonstrate that such a holistic approach that analyses legal, political and institutional dimensions in its own right could be useful to detect mechanisms cutting across political regimes and actors.

\footnotetext{
' While the journal has widely circulated both in hardcopy and online, there are no statistical data available on the scope of journal's readership.

ii While its' first issue was published in January 2012, it seems to come to a halt after its $16^{\text {th }}$ issue published at the end of 2016 in the aftermath of the failed coup attempt.

ii In the editorial of the last issue, it is noted that "the main agenda of the [seemingly the last publically announced YVDK] meeting was "fight against FETO and action plan." While problems related to language, culture, family and social life, racism and xenophobia were gathered during the meeting, it was also decided that a "Diaspora Strategy Act" would be submitted within the coming six months to YVDK by the working groups composed of related public institutions, universities and NGOs, (Editorial, Issue 16, 2016). While its first appointed members' term of office ended at the end of 2016, at the moment even the link to its website is not active. (accessed 07.03.2018)

iv Authors' translation and emphasis.

vFull report in turkish can be found here: https://www.tbmm.gov.tr/sirasayi/donem24/yil01/ss376 Cilt2.pdf (accessed 07.03.2018)

vi http://www.cumhuriyet.com.tr/haber/siyaset/511319/Tayyip Erdogan in 12 Eylul ozlemi.html\# (accessed 07.03.2018)

vii http://www.aksam.com.tr/guncel/evrenin-hainlerine-anavatan-kucak-acti/haber-228318 (accessed 06.03.2018)

viii Since July 2016, Turkey is reported to request the arrest of over 800 citizens from Germany. https://www.dw.com/tr/türkiyeden-almanyaya-yüzlerce-yakalama-talebi/a-45551231 (accessed 25.09.2018)

ixhttps://www.birgun.net/haber-detay/soylu-55-bin-665-kisi-tutuklandi-195145.html

(accessed 06.03.2018)

$\times$ See the report in note 5 .

xi i.e. https://www.theguardian.com/world/2017/mar/12/netherlands-bars-turkish-ministers-as-naziremnant-dispute-escalates (accessed 06.03.2018)
} 


\section{REFERENCES}

Abadan-Unat, N, Cidam V, Cinar D, Kadirbeyoglu Z, Kaynak S, Ozay B, Tas S. (2014) Voting Behavior of Euro-Turks and Turkey's Presidential Elections of 2014, Friedrich Ebert Foundation.

Adamson, Y. (2017) 'Making a homeland, constructing a diaspora: The case of Taglit-

Birthright Israel,' Political Geography, 58:14-23.

Agamben, G. (2005) State of Exception. Chicago: Chicago University Press.

Akkoyunlu, K., Öktem, K. (2016) ‘Existential insecurity and the making of a weak authoritarian regime in Turkey,' Southeast European and Black Sea Studies, 16(4), 505-527.

Aksel, D. B. (2014) Kins, Distant Workers, Diasporas: Constructing Turkey's Transnational Members Abroad, Turkish Studies, 15:2, 195-219.

Aydin, Y. (2014) 'The New Turkish Diaspora Policy: Its Aims, Their Limits and the Challenges for Associations of People of Turkish Origin and Decision-makers in Germany', SWP Research Paper, downloadable from https://www.swpberlin.org/fileadmin/contents/products/research papers/2014 RP10 adn.pdf

Baser, B. (2015) 'Gezi spirit in the diaspora: diffusion of Turkish politics to Europe', in I. David and K. Toktamis (eds.) Everywhere Taksim: Sowing the Seeds for a New Turkey at Gezi, Amsterdam: Amsterdam University Press, 251-266. 
Bauböck, R. (2003) 'Towards a political theory of migrant transnationalism,' International Migration Review, 37 (3), 700-723.

Bauböck, R. (2009) 'The rights and duties of external citizenship', Citizenship Studies, 13(5), 475-499.

Brand, A. L. (2006) Citizens Abroad: Emigration and the State in the Middle East and North Africa, Cambridge: Cambridge University Press.

Brand, A. L. (2010) 'Authoritarian States and Voting from Abroad: North African Experiences', Comparative Politics, 43(1), 81-99.

Brand, A. L. (2014) 'Arab uprisings and the changing frontiers of transnational citizenship: Voting from abroad in political transitions', Political Geography, 41, 54-63.

Brubaker, R. (2005) 'The 'diaspora' diaspora', Ethnic and Racial Studies, 28(1): 1-19.

Burgess, K. (2018) 'States or Parties? Emigrant Outreach and Transnational Engagement', International Political Science Review, 39(3), 369-383.

Collyer, M. (2014) 'Inside out? Directly elected 'special representation' of emigrants in national legislatures and the role of popular sovereignty,' Political Geography, 41, 64-73.

Collyer, M, King, R. (2015) 'Producing transnational space: International migration and the extra-territorial reach of state power', Progress in Human Geography, 39(2), 185-204.

Collyer, M. \& Vathi, Z. (2007) ‘Patterns of Extraterritorial Voting. (Working Paper No.22). University of Sussex Development Research Centre on Migration, Globalisation and 
Poverty, downloadable from http://www.migrationdrc.org/publications/working_papers/WPT22.pdf

Dalmasso, E., Del Sordi A., Glasius M., Hirt, N., Michaelsen, M. Mohammad A.S. and D. Moss (2017) 'Intervention: Extraterritorial authoritarian power', Political Geography, 1-10.

Delano, A. (2014) 'The diffusion of diaspora engagement policies: A Latin American agenda', Political Geography, 41, 90-100.

Delano, A., Gamlen, A. (2014) 'Comparing and theorizing state-diaspora relations', Political Geography, 41, 43-53.

Escobar, C. (2006) 'Migration and citizen rights: The Mexican case,' Citizenship Studies, 10(5), 503-522.

Esen, B., Gümüşçü, S. (2016) 'Rising competitive authoritarianism in Turkey', Third World Quarterly, 37 (9), 1581-1606.

Fairclough, N. (2010) Critical discourse analysis: The critical study of language. Norman Fairclough. London: Longman.

Faist, T. (2007) 'The Fixed and Porous Boundaries of Dual Citizenship', in T. Faist (eds.) Dual citizenship in Europe: From Nationhood to Societal Integration, Aldershot: Ashgate.

Gamlen, A. (2014a) 'The impacts of extra-territorial voting: Swings, interregnums and feedback effects in New Zealand elections from 1914 to 2011‘, Political Geography, 44, 1-8. 
Gamlen A. (2014b) ‘Diaspora Institutions and Diaspora Governance,' International Migration Review, 48 (1), 180-217.

Gamlen, A., Cummings, M., Vaaler, P. M. and L. Rossouw (2013) 'Explaining the Rise of Diaspora Institutions, ' IMI Working Paper 78, International Migration Institute, University of Oxford, downloadable from http://www.migration.ox.ac.uk/odp/pdfs/WP78\%20Explaining\%20the\%20Rise\%20of\%20Dias pora\%20Institutions.pdf

Giglou, R. I., Ogan, C., d'Haenens, L. (2018) 'The ties that bind the diaspora to Turkey and Europe during the Gezi protests', new media \& society, 20(3), 937-955.

Glasius, M. (2017) 'Extraterritorial authoritarian practices: a framework', Globalizations, early view online.

Glick Schiller, N., Basch, L., Szanton Blanc C. (1995) 'From Immigrant to Transmigrant: Theorizing Transnational Migration', Anthropological Quarterly, 68(1), 48-63.

Held, D. (1995) Democracy and Global Order: from the Modern State to Cosmopolitan Governance, Cambridge: Polity.

Holston, J., Appadurai, A. (1999) 'Introduction: Cities and Citizenship’, in J. Holston (ed.) Cities and Citizenship, Durham and London: Duke University Press, 1-21.

Joppke, C. (2016) 'Terror and the loss of citizenship’, Citizenship Studies, 20(6-7), 728-748. 
Kadirbeyoglu, Z. (2007) 'National Transnationalism: Dual Citizenship in Turkey', in T. Faist (ed.) Dual Citizenship in Europe: From Nationhood to Societal Integration, Aldershot: Ashgate, $127-146$

Kapoor, N., Narkowicz, K. (2018) ‘Unmaking citizens: passport removals, pre-emptive policing and the reimagining of colonial governmentalities', Ethnic and Racial Studies, early view online.

Koinova, M. (2018) 'Endorsers, challengers or builders? Political parties’ diaspora outreach in a post-conflict state', International Political Science Review, 39(3), 384-399.

Koinova, M., Tsourapas, G. (2018) 'How do countries of origin engage migrants and diasporas? Multiple actors and comparative perspectives', International Political Science Review, 39(3), 311-321.

Lafleur, J-M. (2011) 'Why do states enfranchise citizens abroad? Comparative insights from Mexico, Italy and Belgium', Global Networks, 11(4), 481-501.

Levitt, P., Jaworsky, B.N. (2007) 'Transnational Migration Studies: Past Developments and Future Trends', Annual Review of Sociology, 33, 129-56.

Linklater, A. (1998) ‘Cosmopolitan Citizenship’, Citizenship Studies, 2 (1), 23-41.

Mavroudi, E. (2007) ‘Diaspora as process: (De)constructing boundaries,' Geography Compass, 1 (3), 467-479.

Mügge, L. (2012) 'Ideologies of nationhood in sending-state transnationalism: comparing Surinam and Turkey', Ethnicities, 13(3), 338-358. 
Okyay, A.S. (2015) Diaspora-making as a State-led Project Turkey's Expansive Diaspora Strategy and its Implications for Emigrant and Kin Populations. Unpublished PhD thesis. European University Institute, Department of Political and Social Sciences, downloadable from http://cadmus.eui.eu/handle/1814/38044

Østergaard-Nielsen, E. (2003) Transnational politics: Turks and Kurds in Germany, London: Routledge.

Østergaard-Nielsen, E., Ciornei, I. (forthcoming) 'Political Parties and the Transnational Mobilisation of the Emigrant Vote', West European Politics.

Öktem, K. (2014). Turkey's new diaspora policy: The challenge of inclusivity, outreach and capacity. Istanbul Policy Centre (IPC) Working Paper, August 2014. Downloadable from http://ipc.sabanciuniv.edu/wp-content/uploads/2014/08/14627_KeremÖktenWEB.18.08.pdf

Palop-García, P., Pedroza, L. (2017) ‘Beyond convergence: unveiling variations of external franchise in Latin America and the Caribbean from 1950 to 2015', Journal of Ethnic and Migration Studies, 43(9), 1597-1616.

Pedroza, L., Palop-Garcia, P. (2017) 'Diaspora policies in comparison: An application of the Emigrant Policies Index (EMIX) for the Latin American and Caribbean region', Political Geography, 60, 165-178.

Ragazzi, F. (2014) 'A comparative analysis of diaspora policies', Political Geography, 41, 7489. 
Rozin, O. (2011) 'Negotiating the right to exit the country in 1950s Israel: Voice, loyalty, and citizenship', Journal of Israeli History, 30(1), 1-22.

Sahin-Mencütek, Z., Erdogan, M. (2015) 'The Implementation of Voting from Abroad:

Evidence from the 2014 Turkish Presidential Election', International Migration, 54(3), 173-187.

Sahin-Mencütek, Z., Baser, B. (2018) ‘Mobilizing Diasporas: Insights from Turkey’s Attempts to Reach Turkish Citizens Abroad', Journal of Balkan and Near Eastern Studies, 20(1), 86105.

Selcuk, O. (2016). 'Strong presidents and weak institutions: populism in Turkey, Venezuela and Ecuador', Southeast European and Black Sea Studies, 16(4), 571-589.

Senay, B. (2012) 'Trans-Kemalism: the politics of the Turkish state in the diaspora', Ethnic and Racial Studies, 35(9), 1615-1633.

Shapiro, A.K. (2016) 'No Exit? Emigration Policy and the Consolidation of Apartheid', Journal of Southern African Studies, 42(4), 763-781.

Somer, M. (2017) 'Conquering versus democratizing the state: political Islamists and fourth wave democratization in Turkey and Tunisia', Democratization, 24(6), 1025-1043.

Soysal, Y. N. (1994) Limits of Citizenship: Migrants and Postnational Membership in Europe, Chicago: University of Chicago Press.

Sykes, P. (2016) 'Denaturalisation and conceptions of citizenship in the "war on terror"', Citizenship Studies, 20(6-7), 749-763. 
Smith, R. C. (2003) 'Diasporic memberships in historical perspective: Comparative insights from the Mexican, Italian, and Polish cases', International Migration Review, 37(3), 724-759.

Tas, H. (2017). 'A history of Turkey’s AKP-Gülen conflict', Mediterranean Politics.

Turcu, A., Urbatsch, R. (2015) ‘Diffusion of Diaspora Enfranchisement Norms: A Multinational Study', Comparative Political Studies, 48(4), 407-437. 